\title{
First record of Scelidotheriinae Ameghino (Xenarthra, Mylodontidae) from the Chasicoan Stage/Age (late Miocene) of Argentina
}

\author{
Primer registro de Scelidotheriinae Ameghino (Xenartha, Mylodontidae) \\ del Piso/Edad Chasiquense (Mioceno tardío) de la Argentina
}

\author{
A.R. Miño-Boilini ${ }^{1}$, R.L. Tomassini² ${ }^{2}$ V.H. Contreras ${ }^{3}$ \\ ${ }^{1}$ Consejo Nacional de Investigaciones Científicas y Técnicas. Centro de Ecología Aplicada del Litoral. Ruta 5, km. 2,5 (3400) \\ Corrientes, Argentina. Email: angelmioboilini@yahoo.com.ar \\ ${ }^{2}$ Consejo Nacional de Investigaciones Científicas y Técnicas-INGEOSUR. Departamento de Geología, Universidad Nacional \\ del Sur. San Juan 670 (8000) Bahía Blanca, Argentina \\ ${ }^{3}$ Instituto de Geología E. P. Aparicio (INGEO) y Departamento Geología, Facultad de Ciencias Exactas, Físicas y Naturales, \\ Universidad Nacional de San Juan. Av. Ignacio de la Roza y Meglioli (5400) Rivadavia, Argentina
}

\begin{abstract}
The subfamily Scelidotheriinae constitutes a group of mylodontids widely represented in the Quaternary of South America; however, the fossil record of the Neogene taxa is still scarce. In the present paper, a new specimen of this subfamily, corresponding to a right partial hemimandible with complete dental series, is reported. The material was recovered from the lower levels of the Arenisca Albardón Member of the Loma de Las Tapias Formation (San Juan Province, Argentina), assigned to the late Miocene. This finding represents the first record of a member of the Scelidotheriinae from the Chasicoan Stage/Age and provides new information about the anatomical characteristics and the geographic distribution of the Neogene representatives of this subfamily.
\end{abstract}

Keywords: Tardigrada; sloth; Neogene; Chasicoan Stage/Age; South America

\section{RESUMEN}

La subfamilia Scelidotheriinae constituye un grupo de milodóntidos ampliamente representados en el Cuaternario de América del Sur. Sin embargo, el registro fósil de los taxa del Neógeno es aun escaso. En este trabajo se presenta un nuevo ejemplar de esta subfamilia, correspondiente a un fragmento de hemimandíbula derecha con la serie dentaria completa. El material fue recuperado de los niveles inferiores del Miembro Arenisca Albardón de la Formación Loma de Las Tapias (Provincia de San Juan, Argentina), asignados al Mioceno tardío. Este hallazgo representa el primer registro de un Scelidotheriinae para el Piso/Edad Chasiquense y aporta nueva información sobre las características anatómicas y la distribución geográfica de los representantes neógenos de esta subfamilia.

Palabras clave: Tardigrada; perezoso; Neógeno; Piso/Edad Chasiquense; América del Sur

Citation / Cómo citar este artículo: A.R. Miño-Boilini et al. (2014). First record of Scelidotheriinae Ameghino (Xenarthra, Mylodontidae) from the Chasicoan Stage/Age (late Miocene) of Argentina. Estudios Geológicos, 70(1): e007. doi: http://dx.doi.org/10.3989/ egeol.41551.291.

Copyright: (c) 2014 CSIC. This is an open-access article distributed under the terms of the Creative Commons Attribution-Non Commercial (by-nc) Spain 3.0 License. 


\section{Introduction}

From a taxonomic perspective, the Scelidotheriinae, typified by Scelidotherium Owen, 1839, are the least diversified of the Mylodontidae and the only ones which, despite their wide geographic distribution in South America, had no involvement in the Great American Biotic Interchange (McDonald \& Perea, 2002; Woodburne et al., 2006). Their representatives include middle-sized ground sloths characterized by an elongated and tubular skull, parallel dental series, laterally compressed teeth, flattened femur, and a concave cuboidal facet on the astragalus (e.g. McDonald \& Perea, 2002; Corona et al., 2013). Gaudin (2004) indicated that the monophyly of this subfamily is supported by as many as 24 unambiguous synapomorphies, six of which are exclusive to the clade.

In South America, the Scelidotheriinae are represented from the middle Miocene to the early Holocene, mainly in Argentina, Bolivia, Brazil, Chile, Ecuador, Peru, and Uruguay (McDonald, 1987; 1997; Miño-Boilini, 2012). The studies related to the Quaternary representatives of this subfamily have increased in recent years (e.g. Dantas \& Zucon, 2007; Cartelle et al., 2009; Miño-Boilini \& Carlini, 2009; Corona et al., 2013); however, the knowledge of the Neogene taxa is still scarce (e.g. Ortega-Hinojosa, 1967; Aramayo, 1988; Miño-Boilini et al., 2011; Pujos et al., 2012). Particularly in Argentina, remains of the Neogene representatives have been recovered in different regions (Fig. 1) from levels assigned to the middle Miocene (Friasian), middle-late Miocene (Mayoan), late Miocene (Huayquerian), early Pliocene (Montehermosan) and late Pliocene (Chapadmalalan).

The goal of this work is to describe and analyze new material, corresponding to a hemimandible of Scelidotheriinae, recovered from the lower levels of the Arenisca Albardón Member of the Loma de Las Tapias Formation (San Juan Province, west of Argentina). This specimen represents the first record of a member of this subfamily from the Chasicoan Stage/Age (late Miocene).

\section{Geographic and stratigraphic setting}

The fossiliferous locality of Loma de Las Tapias $\left(31^{\circ} 28^{\prime} \mathrm{S}, 68^{\circ} 40^{\prime} \mathrm{W}\right)$ is located approximately 20 $\mathrm{km}$ northwest of San Juan city (San Juan Province,
Argentina) (Fig. 1). The specimen was recovered in the lower levels of the Arenisca Albardón Member of the Loma de Las Tapias Formation (Fig. 2), which is exposed in numerous areas in this locality. The deposits of this member include intercalations of conglomerates, conglomeratic and tuffaceous sandstones and mudstones, corresponding to an alluvial plain environment associated with braided rivers (Suvires \& Contreras, 2010). On the basis of the faunal assemblage, radiometric datings and magnetostratigraphic studies, the fossil-bearing level was assigned to the late Miocene. From a biostratigraphic point of view, it corresponds to the Chasicoan Stage/Age (Contreras \& Baraldo, 2010).

\section{Materials and methods}

The material is deposited at the Instituto y Museo de Ciencias Naturales, Universidad Nacional de San Juan (San Juan Province, Argentina), under the acronym PVSJ-22. Comparisons were made with different Scelidotheriinae from the Argentine Neogene: Sibyllotherium guenguelianum (MLP 90-XII-31-5, holotype), Scelidotherium parodii (MACN 13598, MACN 13599), Proscelidodon patrius (MACN A-224, holotype) and Proscelidodon gracillimus (MACN 8470, holotype). The taxa Proscelidodon almagroi, Proscelidodon rothi and Neonematherium flabellatum Ameghino were not considered for the present evaluation given that the types and referred specimens lack mandibles or are isolated lower teeth. In the present work, we followed ScillatoYané (1977) in considering Nematherium in the Subfamily Nematheriidae. According to Gaudin (2004), Nematherium is the sister group of the remaining mylodontids.

Other comparisons were made with Quaternary species of Scelidotheriinae from Argentina, Brazil, and Ecuador: Scelidotherium leptocephalum (BM(NH)M 16579), Scelidodon tarijensis (MACN 10159), Scelidodon chiliensis (ROM 4571), Catonyx cuvieri (MCL 22685) and Valgipes bucklandi (MCL 22429).

Institutional abbreviations: $\mathrm{BM}(\mathrm{NH}) \mathrm{M}$ : Natural History Museum (London, England); MACN: Museo Argentino de Ciencias Naturales "Bernardino Rivadavia" (Buenos Aires, Argentina); MCL: Museu 


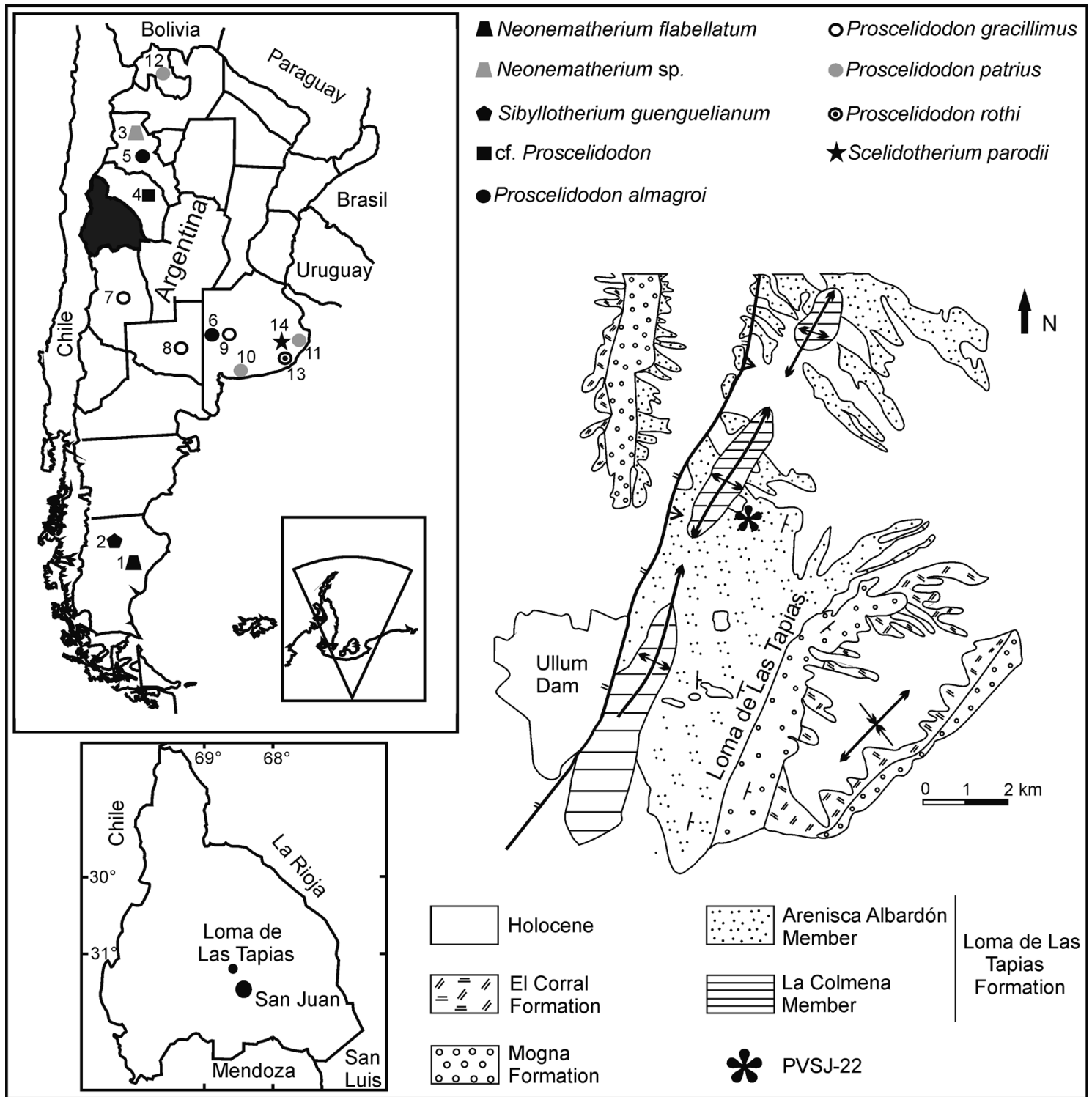

Fig. 1.-Location map showing Loma de Las Tapias locality, San Juan Province, Argentina. Numbers indicate Neogene Scelidotheriinae-bearing localities; 1. Laguna Blanca (Santa Cruz Province); 2. Cerro Guenguel (Santa Cruz Province); 3. Valle del Cajón (Catamarca Province); 4. Sierra de Los Colorados (La Rioja Province); 5. Andalhuala (Catamarca Province); 6. Laguna de Los Paraguayos (Buenos Aires Province); 7. San Carlos (Mendoza, Province); 8. Salinas Grandes de Hidalgo (La Pampa Province); 9. Guaminí-Epecuén (Buenos Aires Province); 10. Farola Monte Hermoso (Buenos Aires Province); 11. Mar del Plata (Buenos Aires Province); 12. Maimará (Jujuy Province); 13. Barranca de Los Lobos (Buenos Aires Province); 14. Arroyo Durazno (Buenos Aires Province).

de Ciências Naturais da Pontifícia Universidade Católica de Minas Gerais (Belo Horizonte, Brazil); MLP: Museo de La Plata (Buenos Aires, Argentina); PVSJ: División Paleontología de Vertebrados, Instituto y Museo de Ciencias Naturales, Universidad Nacional de San Juan (San Juan, Argentina); ROM: Royal Ontario Museum (Toronto, Canada).
Anatomical abbreviations: $\mathrm{mf}$, lower molariform; MD: mesiodistal; LL: labiolingual.

\section{Systematic paleontology}

Superorder Xenarthra Cope, 1889

Order Tardigrada Lathan \& Davis in Forster, 1795 
Family Mylodontidae Gill, 1872

Subfamily Scelidotheriinae Ameghino, 1904

Scelidotheriinae indet.

Figure 3A-B

\section{Type genus: Scelidotherium Owen, 1839.}

Referred specimen: PVSJ-22, right hemimandible fragment with complete dental series (mfl-mf4).

Geographic and stratigraphic provenance: Loma de Las Tapias locality (San Juan Province, Argentina), lower levels of the Arenisca Albardón Member of the Loma de Las Tapias Formation. Late Miocene (Chasicoan Stage/Age).

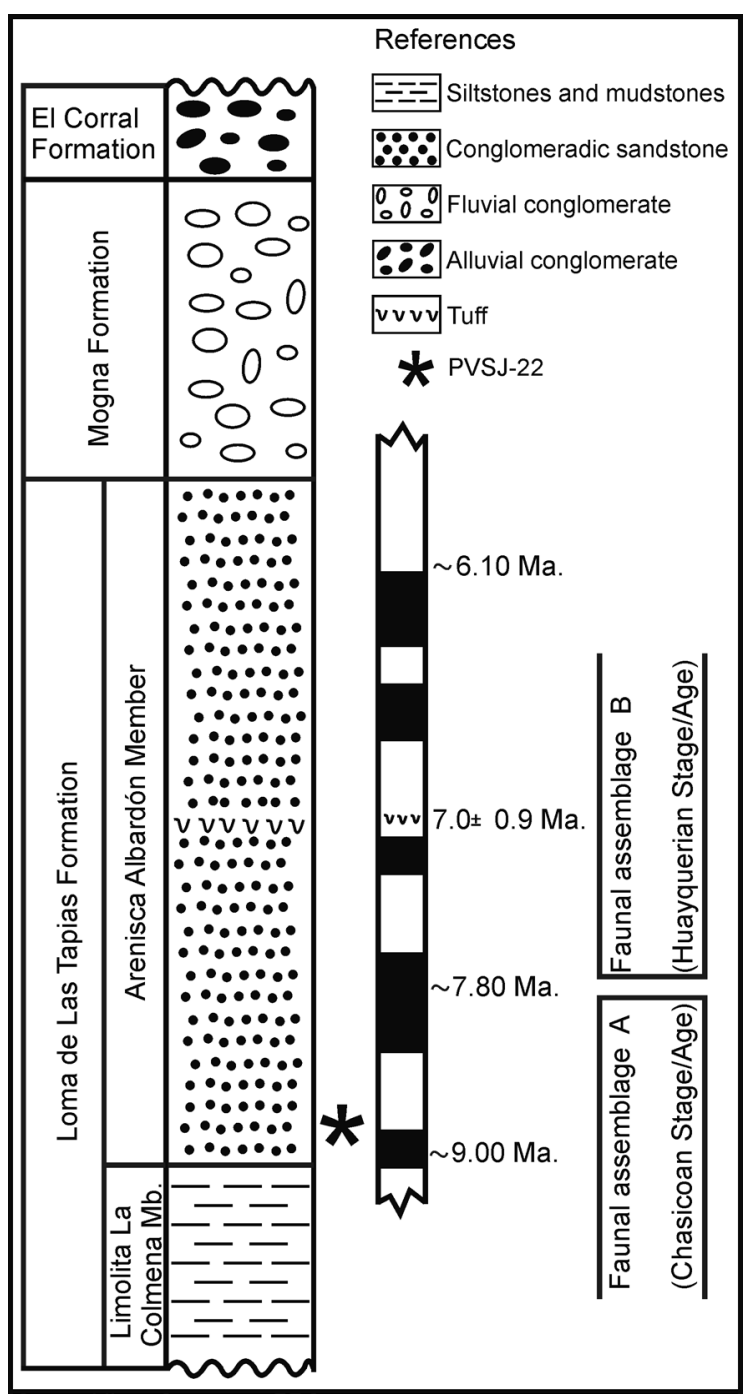

Fig. 2.-Stratigraphic section at Loma de Las Tapias locality.

\section{Description and comparisons}

The preservation of the specimen is very poor, intensely affected by weathering and lacking some parts. The complete dental series (mfl-mf4) was preserved but the occlusal surfaces of all the teeth are broken. These conditions substantially hindered the recognition and description of some morphological characteristics as well as the possibility to measure some features such as the alveolar length and the depth at the level of mf3.

The horizontal ramus is dorsoventrally low (Table 1), with a convex ventral margin (Fig. 3A). These characteristics are also present in the other Neogene Scelidotheriinae here analyzed. There is a progressive increase in the teeth dimensions from $\mathrm{mf1}$ to $\mathrm{mf} 4$ (Fig. 3B), as in all Scelidotheriinae. Additionally, there is no diastema between the first tooth (mf1) and the second ( $\mathrm{mf} 2)$, which is also a diagnostic feature of the subfamily. The teeth are broken at the occlusal surface but are sufficiently preserved to see that they do not have the truncated pyramid shape, indicative of juveniles.

The mf1 (Fig. 3A-B) shows a boomerang-like pattern, with a labiolingual diameter smaller than the

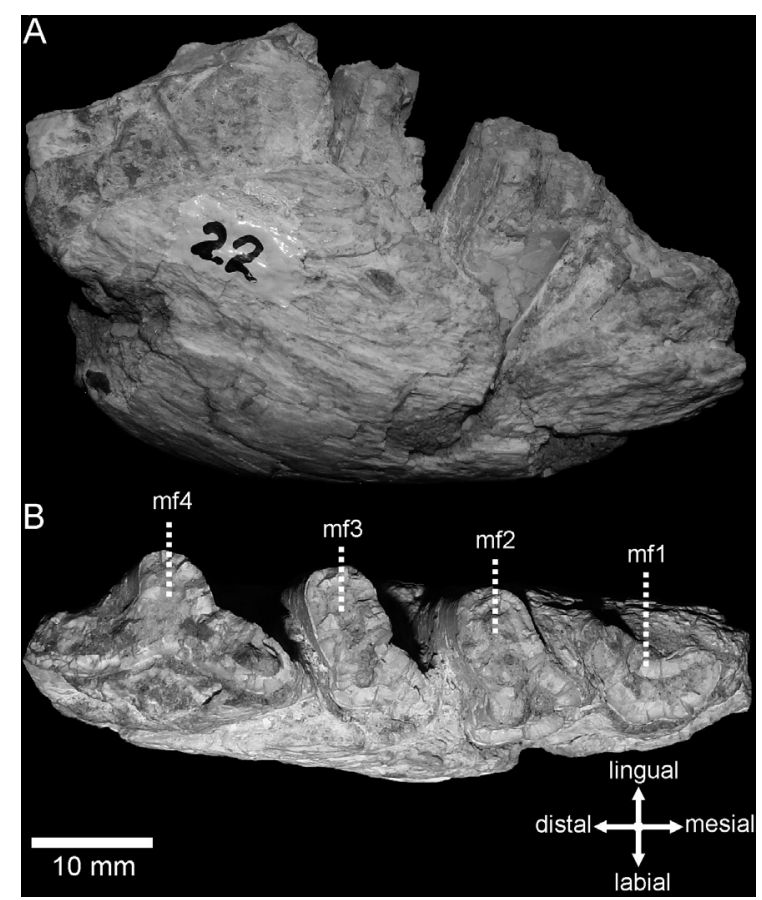

Fig. 3.- Right partial hemimandible (PVSJ-22). A. lateral view; B. occlusal view. 
mesiodistal one (Table 1), as in all the representatives of Scelidotheriinae. The labial side presents a small-sized lobe, well developed and located in the middle of the tooth. This feature can be observed in S. leptocephalum, $S$. tarijensis, $S$. chiliensis, $P$. patrius, $P$. gracillimus and $S$. guenguelianum. In the case of $C$. cuvieri, $V$. bucklandi and S. parodii, while this lobe is also present in the middle section, it is slightly less pronounced than in the remaining taxa.

The $\mathrm{mf} 2$ (Fig. 3A-B) is quadrangular, with its maximum diameter (Table 1) oblique to the sagittal plane, as in all Scelidotheriinae. The labial side presents a slight groove parallel to the major axis of the tooth, delimiting two labial lobes, as it occurs in S. leptocephalum, V. bucklandi, P. gracillimus, $S$. guenguelianum and S. parodii. Conversely, no labial groove is recognized in $S$. tarijensis, $S$. chiliensis, C. cuvieri or P. patrius.

The mf3 (Fig. 3A-B) is subquadrangular, with its maximum diameter (Table 1) oblique to the sagittal plane, as in all Scelidotheriinae. Coinciding with $\mathrm{mf}$, the labial side shows a slight groove, parallel to the major axis of the tooth, separating the labial side into two lobes. This feature is shared with $P$. gracillimus, S. guenguelianum, S. parodii, S. leptocephalum, $S$. tarijensis, $S$. chiliensis, $C$. cuvieri and $V$. bucklandi. Conversely, this labial groove is not present in P. patrius.

The mf4 (Fig. 3A-B) is trilobate as in all Scelidotheriinae, and presents a wider mesiodistal extension than the rest of the teeth (Table 1). The anterior lobe is more extended in mesiodistal sense

Table 1.-Measurements of the hemimandible and the lower teeth

\begin{tabular}{lc}
\hline PVSJ-22 & Measurements $(\mathrm{mm})$ \\
\hline Hemimandible & 58.43 \\
Length & 17.09 \\
Width & 33.42 \\
Height & \\
Lower teeth & 70.32 \\
mf1-mf4 length & $12.70 \times 8.16$ \\
Diameter mf1 (MD $\times$ LL) & $10.23 \times 13.46$ \\
Diameter mf2 (MD $\times$ LL) & $10.76 \times 13.46$ \\
Diameter mf3 (MD $\times$ LL) & $21.33 \times 12.02$ \\
Diameter mf4 (MD $\times$ LL) & \\
\hline
\end{tabular}

with respect to the other two lobes, as in $S$. tarijensis, S. chiliensis, C. cuvieri, V. bucklandi, P. patrius, $P$. gracillimus and $S$. guenguelianum. In $S$. leptocephalum and $S$. parodii, this lobe is less extended. The central lobe is slightly developed and in oblique position respect to the sagittal plane, whereas the posterior lobe is curved towards the lingual side, characteristics present in all the representatives of the subfamily Scelidotheriinae.

\section{Discussion and conclusions}

The specimen PVSJ-22 is assigned to Scelidotheriinae on the basis of the following morphological characteristics: 1) $\mathrm{mfl}$ with a boomerang-like pattern, and with a labial lobe; 2) absence of diastema between $\mathrm{mfl}$ and $\mathrm{mf}$; 3) $\mathrm{mf} 2$ and $\mathrm{mf3}$ with the maximum diameter oblique to the sagittal plane and development of a groove in the labial side; and 4) trilobate $\mathrm{mf} 4$, with the posterior lobe lingually curved.

This new specimen shares characteristics with the different Scelidotheriinae studied, particularly with the Neogene representatives. However, considering the poor preservation of the material, the scarcity of homologous remains available for comparison and the absence of detailed revisions of the different MioPliocene taxa, for the moment we have opted to keep the taxonomic assignment only at the subfamily level.

The Neogene Scelidotheriinae taxa known from Argentina (Fig. 1) include: N. flabellatum from the middle Miocene (Friasian) and S. guenguelianum from the middle-late Miocene (Mayoan) of Santa Cruz; Neonematherium sp. from the late Miocene (Huayquerian) of Catamarca; cf. Proscelidodon from the early Pliocene (Montehermosan) of La Rioja; $P$. almagroi from the late Miocene (Huayquerian) of Catamarca and Buenos Aires; P. gracillimus from the late Miocene (Huayquerian) of Mendoza, La Pampa and Buenos Aires; P. patrius from the late Miocene (Huayquerian) of Jujuy and from the early Pliocene (Montehermosan) and late Pliocene (Chapadmalalan) of Buenos Aires; and P. rothi and $S$. parodii from the late Pliocene (Chapadmalalan) of Buenos Aires (McDonald, 1987; Esteban, 1991; Scillato-Yané \& Carlini, 1998; Rodríguez-Brizuela \& Tauber, 2006; Miño-Boilini et al., 2011; MiñoBoilini, 2012; Pujos et al., 2012). 
The evidence available (faunal assemblage, radiometric datings and magnetostratigraphic studies) for the Arenisca Albardón Member of the Loma de Las Tapias Formation allows assigning the new specimen to the late Miocene, particularly to the Chasicoan Stage/Age. Although the material is scarce and poorly preserved, this finding is interesting since it represents the first record of a member of the Scelidotheriinae from this stage/age. On the other hand, it provides new information about the anatomical characteristics and the geographic distribution of the Neogene representatives of this subfamily, which, as previously mentioned, are poorly represented and lack in-depth studies.

This record constitutes the first mention of a Mylodontidae for the Tertiary of San Juan Province and increases the taxonomic diversity of the Tardigrada from Loma de Las Tapias Formation, represented only by scarce remains assigned to the families Megatheriidae, Nothrotheriidae and Megalonychidae (Contreras \& Baraldo, 2010).

\section{ACKNOWLEDGMENTS}

We thank R. Martínez (Instituto y Museo de Ciencias Naturales, Universidad Nacional de San Juan, Argentina) for facilitating access to the specimen PVSJ-22. We also thank A. Currant (BMNH), C. Cartelle (MCL), K. Seymour (ROM), A. Kramarz and L. Cruz (MACN), and M. Reguero and L. Pomi (MLP), for granting access to collections under their care. Comments of the editor José-María Cebriá, G. McDonald and an anonymous reviewer have certainly improved the manuscript. Consejo Nacional de Investigaciones Científicas y Técnicas (CONICET) provided financial support.

\section{References}

Ameghino, F. (1904). Nuevas especies de mamíferos cretáceos y terciarios de la República Argentina. Anales de la Sociedad Científica Argentina, 58: 241-291.

Aramayo, S.A. (1988). Nuevos restos de Proscelidodon sp. (Edentata, Mylodontidae) del yacimiento de Monte Hermoso (Plioceno inferior a medio), provincia de Buenos Aires, Argentina. Estudio morfológico funcional. II Jornadas Geológicas Bonaerenses, Buenos Aires, 2: 99-107.

Cartelle, C.; De Iuliis, G. \& Lopes-Ferreira, R. (2009). Systematic revision of tropical brazilian scelidotheriine sloths (Xenarthra, Mylodontoidea). Journal of Vertebrate Paleontology, 29: 555-566. http://dx.doi. org/10.1671/039.029.0231.
Contreras, V.H. \& Baraldo, J.A. (2010). Calibration of the Chasicoan-Huayquerian stages boundary (Neogene), San Juan, western Argentina. In: Cenozoic Geology of the Central Andes of Argentina (Salfity, J.A. \& Marquillas, R.A., eds.). SCS Publisher, Salta, $111-121$.

Cope, E.D. (1889). The Edentata of North America. American Naturalist, 23: 657-664. http://dx.doi. org/10.1086/274985.

Corona, A.; Perea, D. \& McDonald, H.G. (2013). Catonyx cuvieri (Xenarthra, Mylodontdae, Scelidotheriinae) from the late Pleistocene of Uruguay, with comments regarding the systematics of the subfamily. Journal of Vertebrate Paleontology, 33: 1214-1225. http:// dx.doi.org/10.1080/02724634.2013.764311.

Dantas, M.A. \& Zucon, M.H. (2007). Occurrence of Catonyx cuvieri (Lund, 1839) (Tardigrada, Scelidotheriinae) in the late Pleistocene-Holocene of Brazil. Revista Brasileira de Paleontologia, 10: 129-132. http://dx.doi.org/10.4072/rbp.2007.2.06.

Esteban, G.I. (1991). Nuevos restos de Neonematherium (Edantata-Scelidotheriinae), provenientes del Valle del Cajón, provincia de Catamarca, Noroeste Argentino. Ameghiniana, 28: 407-408R.

Gaudin, T.J. (2004). Phylogenetic relationships among sloths (Mammalia, Xenarthra, Tardigrada): the craniodental evidence. Zoological Journal of the Linnean Society, 140: 255-305. http://dx.doi. org/10.1111/j.1096-3642.2003.00100.x.

Gill, T. (1872). Arrangement of the families of mammals with analytical tables. Smithsonian Miscellaneous Collections, 11: 1-98.

Latham, J. \& Davies, H. (1795). Faunula indica; appendix. In: Zoologia indica, 2nd edition (Forster, J.R., ed.). Editorial Secunda, Halle, 38 pp.

McDonald, H.G. (1987). A Systematic Review of the Plio-Pleistocene Scelidotherinae Group Sloth (Mammalia: Xenarthra: Mylodontidae). Ph.D. thesis, University of Toronto, $478 \mathrm{pp}$.

McDonald, H.G. (1997). Xenarthrans: Pilosans. In: Vertebrate Paleontology in the Neotropics. The Miocene Fauna of La Venta, Colombia (Kay, R., Madden, R.H., Cifelli, R.L. \& Flynn, J.J., eds.). Smithsonian Institution Press, Washington D.C., 233-245.

McDonald, H.G. \& Perea, D. (2002). The large Scelidothere Catonyx tarijensis (Xenarthra, Mylodontidae) from the Pleistocene of Uruguay. Journal of Vertebrate Paleontology, 22: 677-683. http://dx.doi. org/10.1671/0272-4634(2002)022[0677:TLSCTX]2. $0 . \mathrm{CO} ; 2$.

Miño-Boilini, A.R. (2012). Sistemática y evolución de los Scelidotheriinae (Xenarthra, Mylodontidae) cuaternarios de la Argentina. Importancia bioestratigráfica, paleobiogeográfica y paleoambiental. Ph.D. thesis, Universidad Nacional de La Plata, 317 pp.

Miño-Boilini, A.R. \& Carlini, A.A. (2009). The Scelidotheriinae Ameghino, 1904 (Phyllophaga, Xenarthra) 
from the Ensenadan-Lujanian Stage/Age (Early Pleistocene to Early-Middle Pleistocene-Early Holocene) of Argentina. Quaternary International, 210: 93-101. http://dx.doi.org/10.1016/j.quaint.2009.06.016.

Miño-Boilini, A.R.; Tomassini, R.L.; Oliva, C. \& Manera de Bianco, T. (2011). Adiciones al conocimiento de Proscelidodon Bordas (Mammalia, Xenarthra, Scelidotheriinae). Revista Brasileira de Paleontologia, 14: 269-278. http://dx.doi.org/10.4072/rbp.2011.3.06.

Ortega-Hinojosa, E. (1967). Descripción de los restos de un Scelidotheriinae (Edentata, Mylodontidae) de Edad Huayqueriense. Algunas consideraciones en torno a la filogenia de los Scelidotheriinae. Ameghiniana, 5: $109-118$.

Owen, R. (1839). Fossil Mammalia. In: The Zoology of the Voyage of H.M.S. Beagle (Darwin, C., ed.). Simth, Elder and Co., London, 65-80.

Pujos, F.; Candela, A.; Galli, C.I.; Coira, B.L.; Reguero, M.A.; de los Reyes, M. \& Abello, M.A. (2012). The Scelidotheriine Proscelidodon (Xenarthra: Mylodontidae) from the Late Miocene of Maimará (Northwestern Argentina, Jujuy Province). Ameghiniana, 49: 668-674. http://dx.doi.org/10.5710/AMGH.20.11.2012.593.

Rodríguez Brizuela, R. \& Tauber, A. (2006). Estratigrafía y mamíferos fósiles de la Formación Toro Negro (Neógeno), Departamento Vinchina, noroeste de la provincia de La Rioja, Argentina. Ameghiniana, 4: 257-272.
Scillato-Yané, G.J. (1977). Octomylodontidae: nueva subfamilia de Mylodontidae (Edentata, Tardigrada), descripción del cráneo y mandíbula de Octomylodon robertoscagliai n. sp., procedentes de la Fm. Arroyo Seco (Edad Chasiquense, Plioceno Temprano) del sur de la prov. de Buenos Aires (Argentina). Algunas consideraciones filogeneticas y sistematicas sobre los Mylodontoidea. Publicaciones del Museo Municipal de Ciencias naturales de Mar del Plata "Lorenzo Scaglia", 2: 123-140.

Scillato-Yané, G.J. \& Carlini, A.A. (1998). Nuevos Xenarthra del Friasense (Mioceno medio) de Argentina. Studia Geologica Salmanticensia, 34: 43-67.

Suvires, G. \& Contreras, V.H. (2010). Late Cenozoic geology and geomorphology of the Loma de Las Tapias area, San Juan, west central Argentina. In: Cenozoic Geology of the Central Andes of Argentina (Salfity, J.A. \& Marquillas, R.A., eds.). SCS Publisher, Salta, 427-436.

Woodburne, M.O.; Cione, A.L. \& Tonni, E.P. (2006). Central American provincialism and the Great American Biotic Interchange. In: Advances in late Tertiary vertebrate paleontology in Mexico and the Great American Biotic Interchange (CarranzaCastañeda, O. \& Lindsay, E.H., eds.). Universidad Nacional Autónoma de México, Instituto de Geología y Centro de Geociencias, Publicación Especial, 4: 73-101. 